BANGLADESH JOURNAL OF ISLAMIC THOUGHT, 12(17 \& 18), 2016: 57-66

Copyright $@$ C BIIT

ISSN 1816-689X

\title{
Trade Ethics in the Light of the Qur'an and Sunnah
}

Md. Helal Uddin*

\begin{abstract}
Allah (SWT) says: And do not consume one another's wealth unjustly or send it (in bribery) to the rulers in order that (they might aid) you (to) consume a portion of the wealth of the people in sin, while you know (it is unlawful). Islamic ethics rests largely on its conception of man in relation to Allah (SWT), his own self and the universe and is growing fast among the academicians, producers, consumers, workers, governments as well as the general public. Any trade which functions in brazen disregard to ethical or moral considerations may cause immense harm to the society and be extremely exploitative. The practice of offering bribes to prospective customers, misleading advertisement, sales of spurious and adulterated goods, hoarding and market manipulation at the expense of the consumer, in particular and the society, in general, provide only a few examples. Contrary to it, Islam offers a unique and ideal perspective of trade ethics. It considers trade as a part of one's worship, provided that it is conducted in accordance with the commands of Allah (SWT) and the moral code of conduct prescribed by Islam.
\end{abstract}

Keywords: Trade, Ethics, Islam, Qur'an-Sunnah and Principles.

\section{Introduction}

Due to the collapse of the religious practices all over the world, now human being is considering his action on the basis of ethical views, i.e., what is right and what is wrong. Ethical views differ from culture to culture. To overcome the ethical problem in the area of trade, both nationally and internationally steps have been undertaken by legal and educational systems and by professional and trade corruptions. Surprisingly these views are well parallel to international standard. In this respect this study has been taken in the light of the Qur'an and Sunnah.

\section{Definition of Ethics}

Ethics may be defined as the set of moral principles that distinguish what is right from what is wrong. It is a normative field because it prescribes what one should do and

Dr. Md. Helal Uddin, Chairman, Dept of Islamic Studies, People's University Bangladesh (PUB), E-mail: helalmd1970@gmail.com. 
abstain from doing. Within an Islamic context, the term most closely related to ethics in the Qur'an is Khuluq. The Qur'an also uses a number of terms to describe the concept of goodness: such as Khayr (goodness), birr (righteousness), gist (equity), adl (justice), haqq (truth and right), maruf (known and approved), and taqwa (piety). Pious actions are described as salihat and impious actions are described as sayyiat. ${ }^{1}$

\section{The Islamic Ethical System}

The Islamic ethical system differs from secular ethical systems and moral codes advocated by other religions. Throughout the civilization, secular models assumed moral codes that were transient and myopic since they were based on the values of their human founders. These models generally proposed a system of ethics divorced from religion. At the same time, the moral code adopted by other religions has often stressed values that de-emphasize our existence in this world. For example, Christianity over emphasizes the relation of man to his Creator. Because God is perfect and Omniscient, Muslim has a code that is neither time bound nor biased by human whims. The Islamic code of ethics is enforceable at all times because its Creator and Monitor is closer to man than his jugular vein, and has perfect, eternal knowledge. These are summarized in the following table:

Overview of Six Major Ethical System ${ }^{2}$

\begin{tabular}{|l|l|}
\hline $\begin{array}{l}\text { Alternate } \\
\text { Ethical System }\end{array}$ & Decision Making Criteria \\
\hline Relativism & Ethical decision made on the basis of self-interest and needs. \\
\hline Utilitarianism & $\begin{array}{l}\text { Ethical decisions are made on the basis of the outcomes resulting } \\
\text { from these decisions. An action is ethical it results in the greatest } \\
\text { benefit for the largest number of people. }\end{array}$ \\
\hline Universalism & $\begin{array}{l}\text { Ethical decisions stress the intention of the decision or action. } \\
\text { Similar decision should be reached by everyone under similar } \\
\text { circumstances. }\end{array}$ \\
\hline $\begin{array}{l}\text { Rights } \\
\text { Justice }\end{array}$ & $\begin{array}{l}\text { Ethical decisions stress a single value, liberty, and are based on } \\
\text { individual rights ensuring freedom of choice. }\end{array}$ \\
\hline Eternal Law & $\begin{array}{l}\text { Ethical decisions stress a single value, justice and ensure an } \\
\text { equitable distribution of wealth and benefits. }\end{array}$ \\
\hline $\begin{array}{l}\text { Ethical decisions are made on the basis of eternal law which is } \\
\text { revealed in scripture. }\end{array}$ \\
\hline
\end{tabular}

Source: Beekun I Rafiq (1994). 


\section{The Qura'nic Concept of Trade}

The Qur'an not only permits but also encourages trade transactions. It views the life of man as a continuous process. Man's life, starts at his birth but does not end with his death- Man has to work for and earn success and comforts not only in this world but in the next one as well. In that respect trade are classified as ${ }^{3}$

a) Gainful trade and b) Loosing trade

A gainful trade, according to the Qur'an, consists of three elements:

a) Knowing the best investment.

b) Making the sound judgment.

c) Following the right conduct.

The best investment consists of seeking the pleasure of Allah (SWT). Endurance of physical pain and mental torture as a result of forced expulsion from one's homeland and forbearance of harm, fighting and killing or being killed for the sake of Truth is also a gainful investment.

Preference of that which is al-Iay (good) and halal (lawful) over which is khabith (bad) and haram (unlawful) is considered to be a proof of sound judgments right conduct consisting of good deeds is regarded as the real gainful investment insofar as it ensures a peaceful life in the world as well as success and great recompense in the hereafter. The yard stick with which a person's conduct is to be measured in also prescribed by the Qur'an.

Lack or absence of the elements of a gainful trade is considered to be a losing trade. To be more precise-

1. Bad investment;

2. Unsound judgment and

3. Evil conduct, necessarily end up in a losing trade.

There are, according to the Qur'an, some transactions due to which man plunges himself into complete loss. For example, to buy this world is return for the hereafter. The Qur'an unequivocally maintains that unsound judgment regarding the crucial issues of life do result in tremendous loss. To prefer the life of this world to that of the hereafter/ to prefer khabith or unclean because of its abundance and availability are the examples of unsound judgment. 
Involvement in any activity that is prohibited by Allah (SWT) is evil conduct and to reject the guidance revealed in the Book, to spend ones wealth just to show off, to practice usury are the examples of evil conduct. ${ }^{4}$

\section{Principles and Trade Ethics in Islam}

Trade Ethics, sometimes referred to as management ethics or organizational ethics, simply limits its frame of reference to organizations. However, there is a general consensus among human beings regarding the certain fundamental ethical values. The main problem is how to implement these and how to decide what kind of force could be used for promulgating these. Islam offers its own solution to this problem. It prescribes certain specific guidelines for governing trade ethics. It indemnifies ethically desired forms of trade, specifies the undesirable modes of transactions and enumerates the general ethical rules of trade conduct. Some of those are highlighted with Islamic references:

\section{Prohibition of Riba}

In order to get a clear understanding of the meaning of Riba let us consider the following hadiths and the opinions of the great authorities of Islam. ${ }^{5}$

a. Any loan that brings something additional is Riba.

b. Anyone who recommends a person and then accepts a gift from him has committed Riba.

c. Acceptance of a gift from one's debtor is Riba.

d. Eating in the house of one's debtor is haram.

Riba is directly opposed to the co-operative spirit of Islam. Since riba leads injustice, it creates hatred and services the relations which God wants to be kept intact. Mowdodi (1969) has enumerated the following harmful effect of Riba.

a. It gives rise to greed, excess parsimony, selfishness, hard heartened tyranny and money worship.

b. It encourages hoarding and accumulation of wealth and discourtesy direct investment in productive enterprise.

c. It prevents the circulation of wealth by concentrating it into the coffers of the Capitalist. 
Recounting the evils of Riba sayyid Qutb (1965) concludes that in all cases the burden of interest is eventually borne by the general public. The industrialist and the trade man simply increase their prices and the burden is shifted to the consumers. Allah (SWT) says: Those who consume interast cannot stand (on the day of Resurrection) except as one stands who is bring beaten by Satan into insanity.That is becase they say, "Trade is (just) like interest." But Allah has permitted trade and has forbibden interest.o whoever has received an admonition from his lord and desists may have what is past and his affair rests with Allah (SWT). But whoever returns (to dealing in interest or usury) those are the companions of the fire, they will abide eternally there in. ${ }^{6}$

\section{Adherence to Contracts}

Islam attaches extraordinary importance to the fulfillment of contracts and promises. The basic principles of truth, honesty and trust are involved here. Thus a Muslim trader/manager should keep his trusts, promises and contracts. The following verses of the Qur'an and traditions of the Holy Prophet (SAAS) throw on this fact:

a. O ye who believe! Fulfill your contracts. ${ }^{7}$

b. (True believers are those) Who faithfully observe trust and covenants. ${ }^{8}$

One of the disciples of Prophet (SAAS) said:

I bought something for the Prophet (SAAS) before he received his prophetic commission and as there was something still due to him I promised him that I would bring it to him at his place but I forgot. When I remembered three days later, I went to that place and found him there. He said, That the prophet had been here for three days waiting for you. ${ }^{9}$

\section{Hatred and Fraud (Dishonesty, False Advertisement and Misrepresentation)}

Islam requires its adherent to be honest and trustworthy. A fraud and a cheat do not deserve to be counted as a genuine member of Muslim Ummah. According to the Prophet (SAAS) "He who defrauds does not belong to us. ${ }^{10}$ In this regard Allah (SWT) says "O ye who believe! Betray not the trust of Allah and nor misappropriate knowingly things entrusted to you." One of the most common unethical practices in modern trade is to deceive customers by benching misleading advertisement and public campaigns. Islam strongly condemns all these practices and asks its followers to abstain from them. Allah says in this regard - And do not with hold from people the thing that are their due and commit not evil in the land with intent spread disorder." 11 The Prophet said - "It is not lawful for a Muslim to sell such a commodity that has a defect, except that the defect is shown to the buyer". ${ }^{12}$ 
Thus, there is no scope for fraud, false advertisement, adulterate misrepresentation and concealment of defect in the Islamic framework of trade.

\section{Exactness in Weights and Measures}

One of the oldest ways of cheating in trade is selling commodities in terms of weight or measurement. This include the practice of selling substandard, inferior or adulterate products, which is the most common form of trade frauds these days. Islam declares that justice and balance are the essence of the universe, and hence man, as a part there of, is expected to maintain justice and balance in all sphere of life. The Qur'an and Sunnah repeatedly emphasize the ethical responsibility of trade regarding weight and measurement:

a. Give full measure when you measure and weigh with a balance that is straight. ${ }^{13}$

b. Give just measure and weight do not with hold from the people the things that are due. ${ }^{14}$

\section{Prohibition of Hoarding and Profiteering}

Hoarding, whether of cash or kind, is totally repugnant to the teachings of Islam. In Islamic terminology hoarding of wealth (gold, silver and other cash) is called iktinaz. Hoarding of wealth and preventing its circulation in the society are condemned by the holy Qur'an in severest terms:

And there is those who buy gold and silver and spend it not in the way of God: announce unto them a most grievous penal on the Day when heat will be produced out of that (wealth) in the fire of hell, and with it will be branded their foreheads, their flanks and their backs. This is the (treasure) which be buried. ${ }^{15}$

Prophet (SAAS) said:

One who interferes in the market of the Muslims for increasing the prices, it becomes obligatory for Allah to throw him in the intense fire on the day of judgment. ${ }^{16}$

\section{Fair Treatment of Workers}

It is moral responsibility of trade organizations to take care of the overall welfare and betterment of their employees. They should not treat workers as machines or tools, but as human beings. The following are some Islamic instructions in this regard:

a. "Give the labourer wages before his perspiration be dry."17 
b. "Those who work under you are your brothers. Allah has placed them to Work under you. So if a brother is working under another brother, it is incumbent.

Upon the brother in authority to provide the same food for his younger brother as he takes part himself and gives him the same clothing as he wears and does not put too much workload on his (worker's) shoulders lest he is over burdened and if he overburdened, you should come to his help. ${ }^{18}$

\section{Fair Recruitment Practices}

One of the important areas of public concern is the employment practice of big industrial organization. Discrimination, nepotism, corruption and bribery are much common in big organizations especially in the public sector in the case of employment and promotional decisions. According to Islam, an office or a post is a divine trust and, therefore, it should be offered to the deserving persons and responsibility should be given only to that person who is able to shoulder it and who has the capability to do justice to the trust placed in him. There are evidence revealed by the Qur'an and the Sunnah.

a. "Allah commands you to render back your trust to those to whom they are due and when you judge between man and man, that you judge with justice. ${ }^{19}$

b. "When the administrator is given a job, he should receive his due and should pay the dues of others and then he will be like a brighter in the cause of Allah till he returns home". ${ }^{20}$

c. Who ever recommends the case of persons for appointment and if the recommended person give a gift to him and he accepts it, then he enters a big gate of the major sins. ${ }^{\prime 21}$

\section{Investigation and Verification}

Investigation and verification are essential because they constitute a prelude to right and ethical conduct. Hence, their importance can never be over emphasized. The Qur'an instructs Muslims to probe and verify any given statement or information before making a decision or taking any action. Also, it advises them to investigate about the commodity before purchasing it. This must be done even if there be no other reason, in order to ascertain whether the commodity is Halal or Haram.

\section{Service Motive}

Through his involvement in trade activity a Muslim should intend to provide a needed service to his own community and the humanity at large. His trade activity should not 
be aimed merely at grinding his own axe, or at filling his coffers. In order to let the service motive prevail over the selfish one, a Muslim trade man must be mindful of the following guidelines:

a). Consideration of other's needs and interests: Prophet (SAAS) laid down 22

- None of you can be a true believer unless he loves for his fellow men what he loves for himself.

- All human constitute the family of Allah; the dearest to Allah among them is the one who is the most beneficial towards Allah's family.

- Who ever relieve a fellow human being of a burden in this world, Allah would relieve him of a burden on the Day of Judgment.

b) Providing help free of charge and spending on others:

In order that Muslims provide help to his fellow humans they are urged to spend their wealth on others, they are encouraged to become self-sufficient and produce more than what they need. They are taught that "a giving hand is better than a receiving one". ${ }^{23}$

c) Recommending and supporting a good cause. The Muslims are exhorted to participate in and cooperate with any venture that is good and beneficial to the society.

\section{Prohibition of Hima and Monopoly}

Islam prohibits both Hima and monopoly. The former consists in under extension by the state of persons or group's rights over the rest of the society. The latter, also known as corner marketing stands for the acquisition of similar privileges by using methods other than force. Since both the practices put restrictions on free trade and constrain people to pay unjust and exorbitant prices, they stand directly opposed to the Islamic norms of complete freedom and justice in trade. ${ }^{24}$

\section{Forbidding Destruction of Surplus Produce}

One of the 'modern' methods of profit maximization, adopted by the western trade organizations, is to destroy the surplus product with a view to creating an artificial scarcity of goods and increasing the price. Islam does not allow a person to destroy his produce. Goods and resources actually belong to Allah and man is merely the trustee of those. Some of the Islamic instructions regarding the destruction of product are cited below: 
a. Qur'an says, "And when he turns his back his aim everywhere is spread mischief through the earth and destroy crops and cattle. But Allah loved not disorder on earth" 25

b. The Prophet (SAAS) said, "I dislike three things for you: useless argumentations, wasting goods and excessive questioning. ${ }^{26}$

\section{Protection of Environment}

One of the greatest means of the present day, big industrial plants are the polluters of the environment. Trade men, in their lust for money, are total oblivious of the repercussions of the manufacturing processes on the environment. According to Islam, no individual or organization has the right to utilize its resources in such a way that damage or cause inconvenience to the people or the society in general. The Prophet (SAAS) has said:

There is no scope for causing damage in Islam neither in the case of an independent action nor as a reaction. ${ }^{27}$

\section{Conclusion}

Ethics in modern society has attracted the attention of all people from different cultures and countries. To overcome the ethical problem in the area of trade, both nationally and internationally, steps have been undertaken by legal and educational systems and by professional and trade corporations.

Islam provides some specific ethical guidelines for trade. The principles of faithful observance of contracts, abstaining from false advertising and misrepresentation, accurate measurement non indulgence in hoarding and profiteering, avoiding destruction of surplus produce, prohibition of interest and unlawful trade, fair and just recruitment practices, brotherly treatment of workers, protection from environmental pollution, are only illustrative of trade ethics in Islam. A thorough survey of the Qur'an and Sunnah and early Islamic history can reveal a very comprehensive and rich guidance regarding ethical concept of trade.

\section{References}

1. Beekun RI, Business Ethics in Islam, HIT, USA, 1994, p.3

2. Ibid, p.10

3. Ahmed M, Business Ethics in Islam, HIT, USA, 1995, p. 28. 
4. Ibid, p. 30 .

5. Ibid, p. 106.

6. Al Qur'an, 2: 275.

7. Al Qur'an, 5: 1 .

8. Al Qur'an, 23: 8.

9. Mohiuddin G, Islamic Management, Ph.D thesis, Islamic University Kushtia, 2004, p. 191.

10. Ahmed M, Business Ethics in Islam, HIT, USA, 1995, p. 112.

11. Al Qur'an, 11: 85.

12. Sahee Al-Bukhari, Kitabul Buyu, Hadith No-500.

13. Al Qur'an, 17: 35.

14. Al Qur'an, 7: 85.

15. Al Qur'an, 9: 34-35.

16. Sahee Ibn Majah, Hadith No-2468.

17. Sahee Al-Bukhari, Hadith No-2114.

18. Al-Quran, 4: 58.

19. Ahmed, M, Business Ethics in Islam, HIT, USA, 1995, p. 90.

20. Sahee Al- Muslim, Kitabuzzakat, Hadith No-1034.

21. Ahmad M, Businees Ethics in Islami, HIT, USA, 1995, p. 93.

22. Al Qur'an, 2: 205.

23. Sadeq M, Either in Trade \& Management, Islamic Foundation, Bangladesh, p. 204. 